\title{
復興記念館の建設経緯について \\ 横網町公園内建造物に求められた「日本趣味」について \\ THE CONSTRUCTION PROCESS OF GREAT KANTO EARTHQUAKE MEMORIAL MUSEUM
}

The Nihon-Shumi (Japan-Taste) required to the building in Yokoamicho Park

\author{
姜 明采*1, 内田青蔵*2, 須崎文代*3 \\ Myungchae KANG, Seizo UCHIDA and Fumiyo SUZAKI
}

\begin{abstract}
This paper states concerning about the characteristics of the Nihon-Shumi(Japan-Taste) architecture in Yokoamicho Park. These buildings are additional facilities of the Memorial Hall for Great Kanto Earthquake that is discussed in preceding thesis. The paper clarified the construction process of Great Kanto Earthquake Memorial Museum which was built in 1931. As the result, the design of Memorial Museum has been changed 3 times. The change of the Japanese design came over with details for expressing the NihonShumi(Japan-Taste). Also, it turns out that the museum made a new arrangement the Japanese shrines and temple style.
\end{abstract}

\author{
Keywords : Great Kanto Earthquake Memorial Museum, Great Kanto Earthquake, Hagiwara Koichi, Sano \\ Tosikata, Ito Chuta, Nihon-Shumi(Japan-Taste) \\ 復興記念館, 関東大震災, 萩原孝一, 佐野利器, 伊東忠太, 日本趣味
}

\section{1.はじめに}

東京市は1923（大正 12）年 12 月、被服廠跡（現東京都墨田区横 網町公園一帯）の一部に計画した横網町公園に関東大震災の惨禍を 記念するため、納骨・慰霊・展示の機能を持つ震災記念堂（現東京 都慰霊堂、以下本稿では「震災記念堂」と略称する）の建設を発表 した。震災記念堂は度重なる設計変更を経て 1930（昭和 5）年、建 築家・伊東忠太の設計により竣工したが、これまで設計変更に関す る検討は不十分であった。前稿ではこの点に着目し、震災記念堂が 建築意匠に関する国民多数の希望を意識して寺院建築の和風注 1 意 匠を基礎としつつも、伊東特有の意匠による鉄骨鉄筋コンクリート 構造で完成した「日本趣味」の建築として建設されたことを明らか にした注2)。

さて、翌年の 1931（昭和 6）年には、展示の機能が施された震災 記念堂の新たな付帯施設注 3) として鉄筋コンクリート構造の復興記 念館（現東京都復興記念館、以下本稿では「復興記念館」と略称す る）が建てられた。本稿は、震災記念堂の竣工後に同じ横網町公園 内に建設された復興記念館の建設経緯について明らかにする。

これまで復興記念館に関する研究は、最古の震災記念館注 4) とし て館内に収蔵された資料に注目した成果が多い。ちなみに、山本唯 人は、復興記念館を社会教化の機能を充実した関東大震災の博物館
施設として評価しており注 5)、高野宏泰は、館内の展示内容について 震災の惨禍を記念する当初の計画に復興の要素が加えられたと論じ た注 6)

一方、建築に注目した研究は極めて少なく、建築史的位置づけは 日本建築学会が 1997 (平成 9）年に発表した「東京都復興記念館の 保存に関する要望書」注 7) 以外には殆ど見られない。保存要望書に よると、復興記念館は「昭和初期の建築のデザインのやり方をよく 示寸建物として歴史的に重要な存在」注8) と評価されている。特に、 柱間に合わせて凹凸を付けた立面形状と箱型の玄関を中心に並べた 柱型は、単純な手法で立面に秩序と威篇をもたらした昭和初期の典 型的な立面構成の一つとして挙げられている。また、「頂部には短い 軒を張り出し、瓦を葺くとともに、肘木や斗組を簡略化したような 持ち送り」注 9) で日本趣味を表現したと記され、震災記念堂との意 匠的対応を意識したものと推察されている注 10)。しかし、具体的に 「日本趣味」を表現する意匠的要素の分析はされておらず、建設過程 における設計経緯の詳細注11) も不明である。また、設計者の情報注 12$)$ についても意見が分かれているなど、復興記念館が竣工に至るまで のプロセスには不明な点が多かった。

そこで、本稿は、震災記念堂の付帯施設として建てられた復興記 念館の建設経緯を分析し、前稿に引き続き横網町公園内に用いられ

\footnotetext{
*1 神奈川大学大学院工学研究科建築学専攻 博士後期課程 工学(修士)

*2 神奈川大学工学部建築学科 教授・工博

*3 神奈川大学工学部建築学科 特別助教・博士 (工学)
}

Grad. Student, Dept. of Architecture, Faculty of Engineering, Kanagawa University, M.Eng.

Prof., Dept. of Architecture, Faculty of Engineering, Kanagawa University, Dr.Eng. Assist. Prof., Dept. of Architecture, Faculty of Engineering, Kanagawa University, Dr.Eng. 
た「日本趣味」の建築の特徵を明らかにすることを研究目的とする。

\section{2. 研究資料 · 方法}

本稿は、震災記念堂及び復興記念館の建設事業報告書である『被 服廠跡』注 13) と、東京都慰霊協会所蔵資料のうち震災記念堂の収蔵 庫で発見した文献や図面を主な研究資料として用いた注 ${ }^{14)}$ 。それと ともに、関東大震災が起きた 1923 (大正 12) 年 9 月 1 日より復興記 念館が竣工した年の 1931（昭和 6）年 12 月 31 日までに発行された 建築関係雑誌や新聞より、題名に［震災記念館］［震災復興記念館］ ［復興記念館］［震災博物館］の記述のある全 22 件の記事を収集し た注 ${ }^{15)}$ このうち、『被服廠跡』を除外した全ての資料はこれまで検 討されていなかった新たな資料である。

\section{3. 東京市による震災記念館建設計画について}

3-1. 震災記念堂から独立した復興記念館の建設計画開始

東京市は 1922（大正 11）年 3 月 30 日、陸軍被服廠の移転により 敷地一部を買収して「横網町公園」と命名し、慰安休養と社会教化、 体育奨励を目的とする東京市初の中規模公園を計画した注 ${ }^{16)}$ 。とこ ろで、翌年 9 月の関東大震災により横網町公園を含む被服廠跡では 多大な犠牲者が発生し、東京市は 1923 （大正 12）年 12 月、横網町 公園に納骨・慰霊・展示の機能を持つ震災記念堂の建設とともに震 災記念公園への計画変更を定めた。1924（大正 13）年 2 月、東京市 公園課で公園内の設計を担当するが、東京市の予算不足が主な理由 となり同年 5 月、人々に震災記念堂の建設費百万円と設計競技によ る設計案を募る計画に変更される。一方、東京震災記念事業協会 (以 下、本稿では「協会」と略称する）は東京市社会局が 9 月に主催し た震災復興展覧会注 17) の出品資料を対象に震災記念堂へ展示寸る資 料の収集を開始した注 18)。この後、1925（大正 14）年 3 月に震災記 念堂の設計競技一等案が当選し、翌年 6 月には一等案を基にした実 施案が作成されるが、建設事業の財源であった仏教連合会と本所区 民による意匠の批判及び設計変更一の要求が新聞記事等で大々的に 報じられる。「協会」は批判を踏まえて震災記念堂の設計変更を決定 し、1927（昭和 2) 年 4 月、顧問の伊東忠太に新たな設計案を依頼 する。最終的には、伊東を中心に同顧問の佐野利器、塚本靖、佐藤 功一が新設計案の計画に携わることになった。このうち、新設計案 の基本意匠設計を担った伊東は人々の意向を踏まえて寺院建築の和 風意匠を基調とする方針に取り組むことになる注19)。なお、同年 5 月 4 日の都新聞では、「協会」が震災記念堂内に震災の惨禍を展示寸る 震災記念博物館を計画することが報じられた。一般市民から震災被 害品や当時の状況を表した絵画を募集するという内容であった注 20$)$

さて、1929（昭和 4）年 9 月より東京市政調查会主催の帝都復興 展覧会注21) が開催され、同年 11 月 5 日付の都新聞では震災記念堂 から独立した新たな建築として震災の惨禍と復興事業の内容を展示 する震災記念館の建設の動きが初めて確認できる（図 1)。即ち、記 事によると、横浜震災記念館注 22) が既に建てられたことに対し、東 京市と東京市政調查会が東京でも震災記念館の建設の必要性を協議 していることが報じられている。建物は鉄筋コンクリート構造三階 建てとして翌年春の帝都復興祭までの竣工を目途とし、震災記念堂 の新設計案にも関与した佐野利器注 23) が設計に関わったと記されて いる。ただ、具体的な計画案は示されていないものの、館内には帝
都復興展覧会出品資料の一部を展示し、建設費三十万円を寄付で募 る方針であった注 24)。

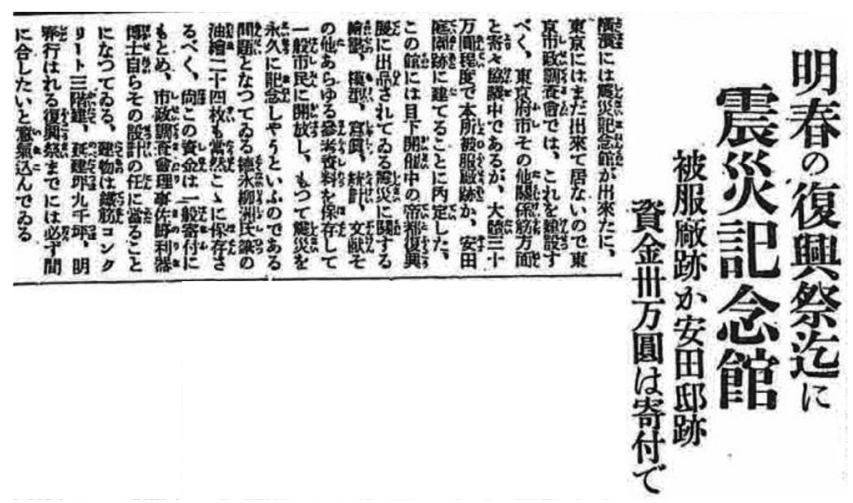

Fig.1 Miyako Newspaper 「Tokyo will be built the Earthquake Museum until the reconstruction festival. It will be located in the old amy dothing depot or Yasda house. And thecostwill bemaintained withdonations.」『MiyakoNewspaper』moming,p.12, 1929.11.5 図 1 都新聞社「明春の復興祭迄に震災記念館 被服廠跡か安田邸 跡 資金世万圓は寄付で」『都新聞』朝刊、p.12、1929.11.5

新聞報道直後の 11 月 9 日、「協会」は東京市長宛に被服廠跡内の 震災記念館建設に関する趣意書「震災記念館設備に關する申請」を 正式に提出した。その内容は以下の通りである。

「東京市政調查會主催復興局東京市後援ノ下二開催相成居候帝都復興 展覧會陳列出品物八洵二帝都ノ震災及復興 ノ資料多數出品セラレ居リ他日更二蒐集困難ノモノ卜被存候本會二於 テ八豫テ建造中二係ル東京震災記念堂内二一部同様計畫有之侯モ規模 狭小充分ノ効果 $コ$ 収メ難キ遺憾有之候二付テハ何卒御市二於テ該展覧 會陳列物等 7 陳列シ大正十二年ノ大震災及帝都ノ復興 7 永久二記念シ 得ベキ記念館等ノ設備二付特二御高配賜り候様致度得貴意候注 25)」

趣意書によると、完成した震災記念堂の展示空間が狭いため、展 覧会資料を展示しながら関東大震災及び帝都復興を永久に記念寸る 記念館を新たに建設したいと記されている。具体的な建築意匠は言 及されていないが、震災記念堂と同様に「協会」の顧問として在籍 した伊東忠太、佐野利器、塚本靖、佐藤功一が関与していたことが 推察される。

この後、建物の名称は震災の惨禍と復興を記念する「震災復興記 念館」となり、本格的な建設計画が着手された。

\section{3-2. 帝都復興祭の動線計画から見る復興記念館の第一案 (計画案)}

都新聞（図 1）に竣工の目途として報じられた帝都復興祭は、帝 都復興事業の完成を祝うため 1930（昭和 5）年 3 月 26 日に開催さ れ、天皇巡幸と記念式典が行われた。特に 24 日の天皇巡幸では震 災・復興関係施設 7 力所を視察することになり注 26)、その対象とな った震災記念堂では行事に向けた敷地内動線計画が行われた（図 2)。 これによれば、前面道路からの進入を想定して紅白幕と横長の奉迎 員参列席を設けた動線計画の詳細が把握できる一方、図面下部に「記 念館」と記された復興記念館の配置が初めて確認できる。この図面 では、「記念館」は凸形の玄関と長方形の空間、背面に小さな台形を 
つなぐ左右対称の形状が具体的に描かれている。

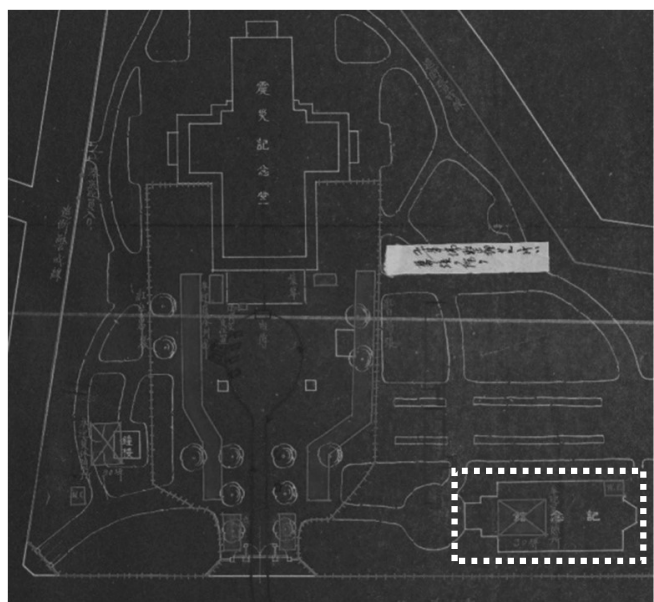

Fig.2 Memorial Museum in the Memorial Hall's flow plan of the Emperor's visit 図 2 天皇巡幸の動線計画に見る復興記念館注 27)

ところで、図 2 の「記念館」と同一形状の図面が震災記念堂の収 蔵庫で新たに発見できた（図 3 5、以下本稿では「第一案」と称す る)。1 枚の図面に描かれた図 3 と図 4 は作図時期や設計者の情報が 不明であるものの、図 3 の平面図に図 2 と同様な形状を含めた各階 の平面計画が描かれていることから、同一の設計として考えられる。 まず、図 3 の詳細を見ると、延面積 $1,267.165 \mathrm{~m}^{2}$ の地下一階地上 二階の構成で、地下室は「便所」と「倉庫」、「下足」、「小使室」、「守 衛室」を設けており、一階は柱のみで区画した主な空間を「陳列室」 とし、正面には「事務室」と「応接」、背面には台形状平面の「休䕀 室」が見られる。中央階段から上がった二階は、柱を囲んで仕切ら れた中央の長方形スペース及びその周囲全体の主な空間を「陳列室」 とし、張り出した正面に「貴賓室」が設けられている。このように、 左右対称に柱を配置した一階と、ホールを中心として周りを廊下の ような空間で計画した二階の平面計画から、第一案は自由な順路で 展覧を可能にしようとした設計意図が読み取れる。

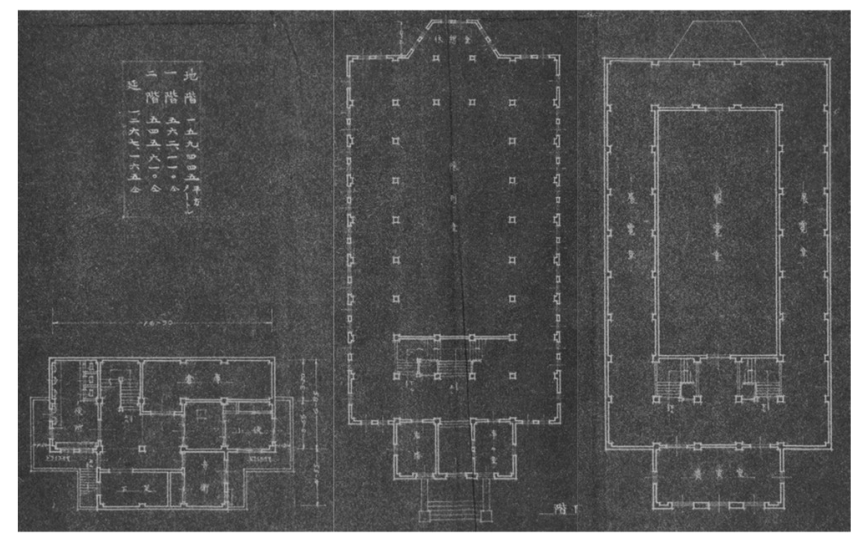

Fig.3 Floor Plan (the $1^{\text {st }}$ design; basement, first, second from the left) 図 3 第一案 平面図（左から地下一階、一階、二階）注28)

また、図 4 の正面図によると、第一案は各層が異なる仕様を用い た立面の外形が左右対称で計画されており、縦長開口部や胴蛇腹、 建物の最上部まで持ち上げた玄関ポーチなど、古典主義様式注 29) を
基調としていたことがうかがえるものであった。

一方、反りのある屋根形状と玄関前の灯篭（図 5）などで社寺建 築の和風意匠が見られる。

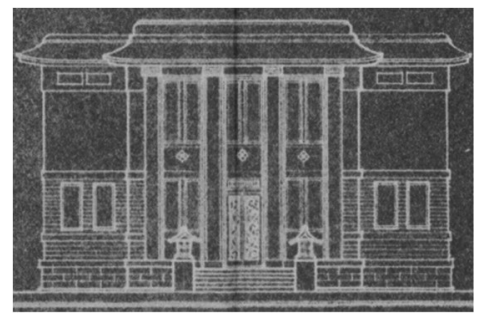

Fig.4 Front View (the $1^{\text {st }}$ design) 図 4 第一案 正面図注 30)

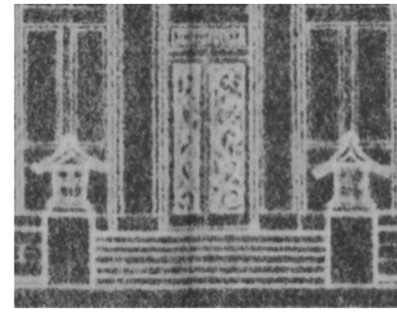

Fig.5 Details (the $1^{\text {st }}$ design) 図 5 第一案の細部装飾注 31$)$
以上、第一案の設計者は不明でありながらも、設計案は建設計画 が発表された 1929 （昭和 4）年 11 月 9 日より図 2 の作図前となる 1930 (昭和 5) 年 3 月 24 日の間に完成したことが考えられる。また、 図 1 の新聞記事からは佐野利器が設計者として関与したと記されて いる。しかし、1930（昭和 5）年 3 月 25 日の都新聞には復興記念館 の設計が東京市公園課課長・井下清注 $\left.{ }^{32}\right)$ を心に行われていると報 じられており注33)、井下清も設計に関わったことが推察できる。

\section{4. 復興記念館の設計変更の経緯}

\section{4-1. 新聞記事に見る復興記念館の第二案}

$1930 （$ 昭和 5）年 9 月 1 日、横網町公園では震災記念堂の竣工式 が行われるとともに建物の前で復興記念館の建設費募金が開始され た。その 2 日後、東京日日新聞には復興記念館建設計画の概要に関 する記事と正面図 1 枚が掲載された（図 5、以下、本稿では「第二 案」と称する)。

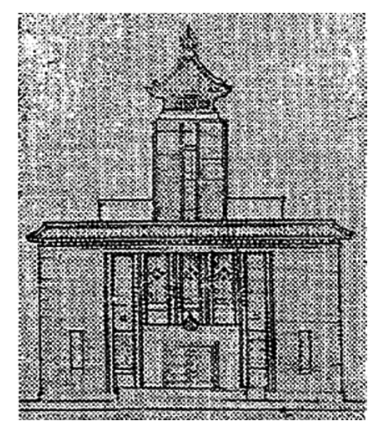

Fig.6 Tokyo Nichi-Nichi Newspaper [Earthquake Reconstruction Memorial」 『Tokyo Nichi-Nichi Newspaper』evening, p.2, 1930.9.3 (the $2^{\text {nd }}$ design) 図 6 東京日日新聞社「震災復興記念館」『東京日日新聞』夕刊、 p. 2、1930.9.3 (第二案) 注 34)

図 6 の正面図に見る第二案は、均一な仕様による長方形の立面形 状に瓦屋根を被せ、方形屋根の上に相輪を持つ塔を加えた大きな変 化が見られる。新聞記事の他に第二案の計画内容を確認できる資料 が無いため、このように計画を変更した経緯は不明であるが、震災 記念堂の設計競技一等案などで塔を設けて記念性の表現を意識した 動きが復興記念館にも反映された可能性が考えられる。

また、肘木、斗組を簡略化した屋根の表現と塔上部に用いた瓦莫 
きの方形屋根や相輪から、屋根部を中心に社寺建築の和風意匠が具 体化されたことが確認できる。

しかし、新聞記事に「二階建て」の記述が見られる一方、第一案 で用いた灯篭が無くなり、玄関はポーチではなく上部に水滴のよう な形状の装飾を加えた一階ほどの高さとなった。こうした設計変更 の経緯や平面計画の詳細、設計者の情報は不明である。

\section{4ー2. 図面に見る復興記念館の第三案（最終案）}

（1）全体計画（1930（昭和 5）年 9 月時点）

復興記念館の建築工事は震災記念堂と同様に戸田組が一般競争入

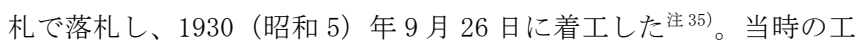
事図面であると考えられる青焼き図面（図 7 11、以下、本稿では 「第三案」と称する）には、「昭和 5 年 9 月」と作図時期が記されて おり、「協会」建築技師・萩原孝一注 36 ) 、技手・今井義男、嘱託員技 師・小野二郎、雇用管理責任者・大関重男の押印が確認できた注 37 。

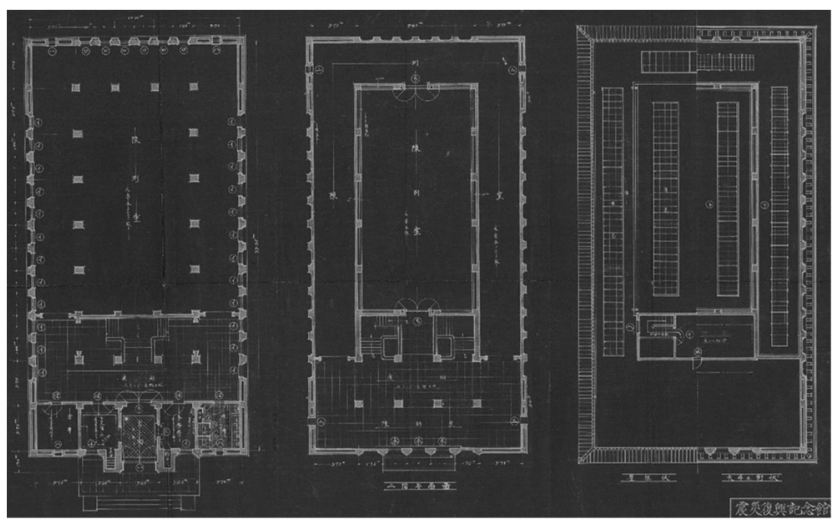

Fig.7 Floor Plan (the $3^{\text {rd }}$ design; first, second, roof from the left) 図 7 第三案 平面図（左から一階、二階、屋根伏）注 38 )

まず、平面計画では（図 7)、第一案で地下室に用いた「倉庫」、 「便所」、「下足預かり所」を一階の正面に移した。また、「休䕀室」 の機能で用いられたアプスのような台形状平面の空間が無くなり、 全体的に長方形のシンプルな形状に変わっている注39)。二階には「貴 賓室」の壁を柱に変更して長方形空間の全てを「陳列室」としてい る。延面積は第一案より約 $90 \mathrm{~m}^{2}$ が縮小された約 $1,177 \mathrm{~m}^{2}$ となって いるが注 40)、全体的な構成に大きな相違点は無く、自由な順路での 展覧を計画した第一案を基に修正したことが分かる。
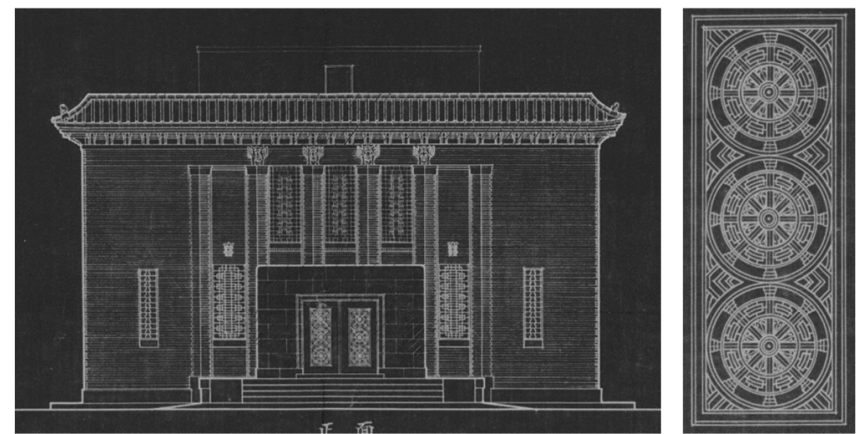

Fig.8 Front View (the $3^{\text {rd }}$ design) 図 8 第三案 正面図注 41)

Fig.9 Omament for entrance door 図 9 正面玄関扉の装飾注 42
また、図 8 の正面図によると、第三案は瓦屋根を用いた長方形の 立面形状で、第二案の塔を除いてシンプルに変更された注43)。

一方、屋根上のパラペットに用いた屋根と肘木、斗組を簡略化し た表現は第二案と同様で、正面玄関の扉に輪宝 ${ }^{44)}$ をアレンジした円 形装飾（図 9）が見られる。これらの点から、第三案は屋根部を含む 細部表現において、社寺建築の和風意匠がモダンでシンプルにアレ ンジされたと考えられる。

なお、正面の柱上部と屋根上部に見る怪獣（図 10・図 11）は震災 記念堂の設計者・伊東の関与が指摘されており 注 45 )、震災記念堂に 異形の怪獣が設けられていることから、同敷地内の意匠的調和への 工夫であると考えられる。

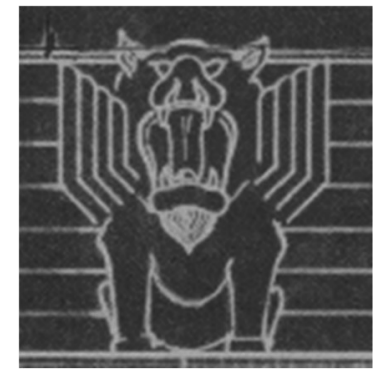

Fig.10 Monster at the top of columns 図 10 正面柱上部の怪獣注 46)

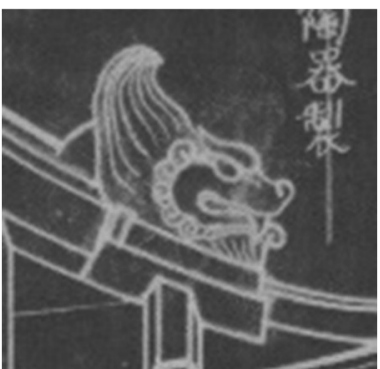

Fig.11 Monster of the rooftop 図 11 屋根上部の怪獣注 47)
このほか、第二案より中央部分が突出した正面の柱形状や、格子 と照明などに繰り返し施した幾何学的な装飾から、アール・デコ様 式注 48)の影響がうかがえる。

（2）玄関設計変更詳細図（1930（昭和 5）年 12 月時点） 第三案の設計を具体化する段階で作図の約 3 ケ月後となる 1930 (昭和 5) 年 12 月 2 日には、玄関周り部材を石からタイルに変更す る工事が行われた注 49)。工事の際に作図されたと考えられる玄関設 計変更詳細図（図 12）では「K1」と「12.2」の文字が確認でき、図 面の設計者は萩原孝一であると考えられる注 50)。また、萩原の経歴 書にも「設計監督 工事主任」注 51) という記述が見られる。瓦屋根 を被せた長方形の立面形状に見る意匠的類似性から、萩原は第二案 の設計から関わった可能性も推察できる。

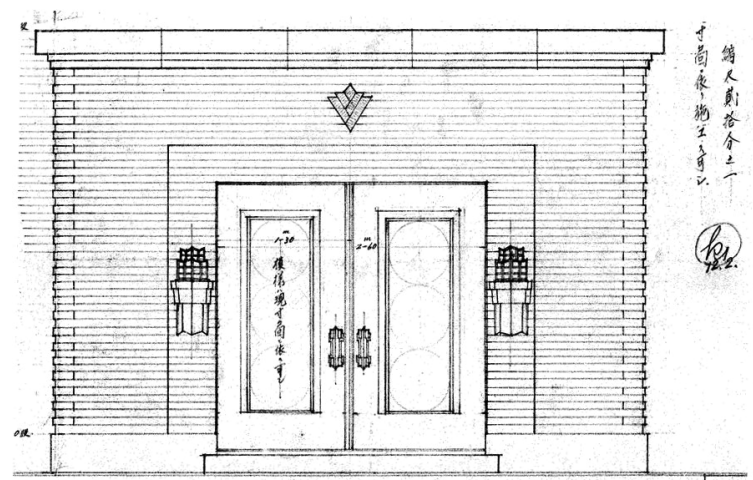

Fig.12 Detail View of the entrance's design change 図 12 復興記念館玄関設計変更詳細図注 ${ }^{52)}$ 
一方、第二案の玄関上部で用いた水滴のような形状の装飾は、逆 三角形を組み合わせた形状に変わり、屝両側の照明にも幾何学的な 装飾が用いられるなど、アール・デコ様式の影響が考えられる意匠 的要素が多く加えられたことが確認できる。

1931 (昭和 6) 年 3 月、建物の正式名称は「復興記念館」と決定 となり、同年 8 月 18 日、竣工式及び開館式を行った注 ${ }^{53)}$ 。

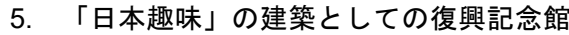

これまでの分析で、復興記念館は 3 回の設計変更を経て 1931（昭 和 6) 年 8 月 18 日に竣工したことが明らかとなった。各案の意匠的 特徴について概観すると、以下の通りである。

まず、第一案は古典主義様式の影響が考えられる長方形の形状に、 反りのある屋根形状や灯篭などで社寺建築の和風意匠が見られた。 一方、第二案では長方形の上部に塔を乗せた形状へ変更され、时木、 斗組を簡略化した瓦屋根と、塔上部に見る反りの強い方形屋根と相 輪など、屋根部を中心に社寺建築の和風意匠の表現が具体化される。 最終的な第三案では、第二案の塔を無くした長方形の形状に、肘木 や斗組を簡略化した瓦屋根、玄関扉の円形装飾など、細部表現に社 寺建築の和風意匠の要素がモダンでシンプルにアレンジされるほか、 アール・デコ様式の影響を受けた装飾的要素も多くうかがえた。

以上の経緯から、復興記念館は計画当初から社寺建築の和風意匠 で「日本趣味」の建築を具現する方針が一貫して計画されたことが 考えられ、屋根部を含む細部表現で確認できた。

さて、最終的な復興記念館の意匠について、竣工式直後である同 月 25 日の『建築雑誌』に掲載された「東京市復興記念館新築工事概 要」では「東洋趣味に依る近世式」注54) と記述され、「東洋趣味」の 建築としている。ちなみに、大正末期から昭和初期までは中国や日 本の社寺建築に影響を受けた意匠を「日本趣味」として捉えた設計 競技当選案や実際の建築が多く、「東洋趣味」は広義の「日本趣味」 として扱われていた注 55)。『建築雑誌』の記事における復興記念館の 意匠説明には、こうした時代背景が反映されたと推察できる。

なお、復興記念館に見る社寺建築の和風意匠が簡略化していく様 子は、東洋風の社寺建築に起因する要素で日本の伝統を表した当時 の傾向は非合理的であると批判が出るなど、一部建築家の間で日本 趣味」を表現する意匠の解棌が変わりつつあったこと注 ${ }^{56)}$ との関連 性がうかがえる。一方で、当時流行したアール・デコ様式の影響も 考えられる。

\section{6. まとめ}

本稿は、震災記念堂の付帯施設として 1931（昭和 6）年に竣工し た復興記念館の建設経緯を分析し、震災記念堂の竣工後の動きとし て前稿に引き続き横網町公園内建造物における「日本趣味」の建築 の計画変更の経緯を明らかにした（表 1)。

当初、関東大震災の惨禍を後世に伝える社会教化、即ち、展示の 機能が与えられた建築は震災記念堂であった。しかし、寄贈資料や 震災関連展覧会の出品資料など数多くの震災及び復興関連資料を保 存するため、新たな展示施設として復興記念館が計画された。こう した復興記念館は、竣工まで大きく三回の設計変更が行われた。
Table1 History of construction of Great Kanto Earthquake Memorial Museum from the reference and newspaper, etc. 表 1【年表】文献・新聞記事等から見る復興記念館の建設経緯

\begin{tabular}{|c|c|c|c|}
\hline $\begin{array}{c}\text { Date } \\
\text { 年月日 }\end{array}$ & $\begin{array}{l}\text { Event } \\
\text { 出来事 }\end{array}$ & $\begin{array}{c}\text { Source } \\
\text { 出典 }\end{array}$ & \begin{tabular}{|c} 
Design \\
設計案注 57) \\
䚺
\end{tabular} \\
\hline 1929.11.5 & 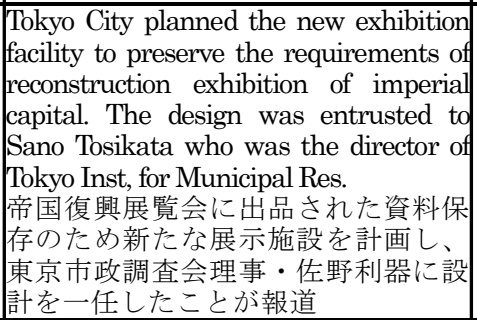 & $\mathrm{B} / \mathrm{E} / \mathrm{F}$ & \\
\hline 1929.11.9 & $\begin{array}{l}\text { Great Kanto Earthquake Association } \\
\text { submitted the prospectus about the } \\
\text { construction of Memorial Museum. } \\
\text { 東京震災記念事業協会が東京市長宛に復 } \\
\text { 興記念館の建設に関する趣意書を提出 }\end{array}$ & A/B & \multirow{2}{*}{\begin{tabular}{|l|}
$\mathbf{1}^{\text {st }}$ design \\
第二案 \\
Japan-Taste \\
「日本趣味」 \\
roof: shrine \\
and temple \\
屋根 : 社寺風 \\
detail: shrine \\
and temple \\
細部 : 社寺風 \\
\end{tabular}} \\
\hline 1930.3.24 & \begin{tabular}{|l|} 
Emperor's visit \\
(reconstruction festival of imperial capital) \\
天皇御巡幸（帝都復興祭）
\end{tabular} & $\begin{array}{l}A / B / C / \\
D / E / F\end{array}$ & \\
\hline 1930.3.25 & $\begin{array}{l}\text { The construction plan of Memorial Museum } \\
\text { wasstudiedby KiyoshiInosita, manager ofthe } \\
\text { departmentofpark, Tokyo City. } \\
\text { 復興記念館の建設計画が東京市公園 } \\
\text { 課課長・井下清を中心に研究されて } \\
\text { いることが報道 }\end{array}$ & $\mathrm{E}$ & \\
\hline 1930.9.1 & $\begin{array}{l}\text { The donation of the construction cost for } \\
\text { Memorial Museum started. } \\
\text { 復興記念館の建設費募金開始 }\end{array}$ & B & \\
\hline 1930.9 .2 & $\begin{array}{l}\text { The design of Memorial Museum was } \\
\text { completed. } \\
\text { 復興記念館の設計案完成 }\end{array}$ & B/D/F & \begin{tabular}{|l|}
$2^{\text {nd }}$ design \\
迕二穿 \\
Japan-Taste \\
「目本趣味」 \\
roof: shrine \\
and temple \\
屋根 : 社寺風 \\
detail: shrine \\
and temple \\
細部 : 社寺風 \\
tower: shrine \\
and temple \\
塔 : 社寺風 \\
\end{tabular} \\
\hline 1930.9 .26 & $\begin{array}{l}\text { The construction work of Memorial } \\
\text { Museum started. } \\
\text { 復興記念館の工事着手 }\end{array}$ & A & $\begin{array}{l}3^{\text {rd }} \text { design } \\
\text { 第三案 } \\
\text { Japan-Taste } \\
\text { 「目本趣味」 } \\
\text { roof: shrine } \\
\text { and temple } \\
\text { 屋根 : 社寺風 } \\
\text { detail: art-deco } \\
\text { 䋨: アルレ・デニ風 } \\
\end{array}$ \\
\hline 1930.11.28 & $\begin{array}{l}\text { Tokyo city and the reconstruction } \\
\text { secretariat donated 67,650yen for the } \\
\text { construction grant of Memorial Museum. } \\
\text { 復興記念館の建築補助金として東京 } \\
\text { 市と復興事務局が } 67,650 \text { 円を寄付 }\end{array}$ & A & \\
\hline 1931.3 & $\begin{array}{l}\text { Tokyo city determined the legal name; Great } \\
\text { Kanto EarthquakeMemorial Museum. } \\
\text { 東京市より「復興記念館」という名称 } \\
\text { が決定 }\end{array}$ & A & \\
\hline 1931.8.18 & $\begin{array}{l}\text { The completion and opening ceremony } \\
\text { were held. } \\
\text { 復興記念館の竣工式及び開館式挙行 }\end{array}$ & $\begin{array}{c}\mathrm{A} / \mathrm{C} / \mathrm{D} / \\
\mathrm{E} / \mathrm{F}\end{array}$ & \\
\hline
\end{tabular}

Source A: 『Theoldclothing depot』 B:Asahi Newspaper C:Yomiuri Newspaper D: Tokyo Nichi-Nichi Newspaper E: Miyako Newspaper F: Hochi Newspaper 出典 $\mathrm{A}$ :『被服廠跡』 $\mathrm{B}$ :朝日新聞 $\mathrm{C}$ :読売新聞 $\mathrm{D}$ :東京日日新聞 $\mathrm{E}$ :都新聞 $\mathrm{F}$ :報知新聞

まず、1929（昭和 4）年 11 月 9 日より翌年 3 月 24 日の間に設計 された第一案は、古典主義様式の影響が考えられる立面に、反りの 
ある屋根形状や灯篭などの細部表現に社寺建築の和風意匠が加えら れた。

しかし、震災記念堂の竣工直後である 1930（昭和 5）年 9 月 3 日 に報じられた第二案は、均一な仕様による長方形の立面形状に肘 木、斗組を簡略化した瓦屋根を被せ、その上に方形屋根と相輪を持 つ塔を加えたものになっていた。こうした設計変更の理由は不明で あるが、第一案より屋根部を中心に社寺建築の和風意匠が具体化さ れたことが読み取れる。

一方、第三案は建築工事が着手される 1930 (昭和 5）年 9 月 26 日 頃に描かれた青焼き図面で確認できる。第二案の塔を除いた形状に、 第一案を基にした長方形の平面計画となっていた。また、时木、斗 組を簡略化した瓦屋根の表現は第二案と同様で、扉の円形装飾が新 しく加えられており、社寺建築の和風意匠をモダンでシンプルにア レンジした様子がうかがえた。このほかに個性的な怪獣も見られ、 正面や玄関周りの細部装飾ではアール・デコ様式の影響が確認でき る。こうした第三案の設計者は、設計図面に記されたサインや本人 の経歴書等から、当時「協会」建築技師として在籍した萩原孝一で あると推察できた。萩原はシンプルでモダンなスタイルの建築に多 く手がけており、そうした作風が第三案のシンプルな形状への変化 に影響を与えた可能性が考えられる。この後、復興記念館は 1931 (昭 和 6) 年 8 月 18 日、竣工式及び開館式を行った。

以上のことから、復興記念館は第一案をベースとして若干の修正 が加えられたものの、屋根部を含む細部表現を中心に社寺建築の和 風意匠で「日本趣味」を具現するという設計方針は一貫していたこ とが考えられる。ところで、「日本趣味」を表現した各案の意匠的要 素には変化が見られ、最終的には社寺建築の和風意匠を簡略化した 傾向がうかがえた。この背景には、他の細部装飾でも確認できるよ うに、当時流行したアール・デコ様式の影響が考えられる。一方で、 中国起源の社寺建築をモチーフとした「東洋趣味」が広義の「日本 趣味」に混乱して捉えられる中で、日本固有の建築的伝統一の要求 が浮上するなど、「日本趣味」を表現する意匠的要素の解釈が進化し つつあった時代性もうかがえる。

このように復興記念館が計画当初から「日本趣味」の建築を念頭 に置いた背景には、震災記念堂と意匠的調和を図ろうとしたことが 推察でき、震災記念堂の付帯施設という建物の性格が建築意匠にも 反映された結果であると考えられる。

\section{謝辞}

本研究は東京都慰霊協会理事長・住吉泰男氏から御助言及び資料 提供など、多大な御協力を賜ったことに深く感謝申し上げたい。

注

注1）本稿では社寺建築の要素を持ち、神社建築や和様・唐様・天勧様を含め たわが国在来の建築様式とする。

注2）震災記念堂の建設経緯については前稿に詳しい(姜明采，内田青蔵，須 崎文代：震災記念堂（1930 年竣工）の建設経緯について, 日本建築学 会計画系論文集, 第 82 巻, 第 734 号, 日本建築学会, pp. 1029-1038, 2017. 4)。

注3）復興記念館の案内パンフレットには、「震災記念堂の付帯施設として建 設された」と記されている（東京都慰霊協会：復興記念館案内，東京都 慰霊協会, 1956.9, ほか)。

注4）阪本真由美：災害の記憶の想起の装置としてのミュージアム， 日本文 化人類学会研究大会発表要旨集，2016(0)，日本文化人類学会，D05,
2016

注5）山本唯人：関東大震災の記念物・資料保存活動と「復興記念館」一震災 後における「公論」の場の社会的構築と「災害展示」(特集 学術振興会 人文・社会科学振興プロジェクト 多元的共生社会の構築-被災地の現場 から), 社会学雑誌, 第 23 号, 神戸大学社会学研究会, pp. 3-16, 2006

注6）高野宏康：「震災の記憶」の変遷と展示-復興記念館および東京都慰霊堂 収蔵・関東大震災関係資料を中心に，年報非文字資料研究，第 6 号，神 奈川大学日本常民文化研究所非文字資料研究センター, pp. 42-43, 2010.3, ほか

注7）戦争の惨禍を記念する都平和祈念館との合築による復興記念館の建て 替え計画に反対した日本建築学会が、復興記念館の建築的価値について 論じたものである (日本建築学会：東京都復興記念館の保存に関する要 望書, 1997.3.24)。

注8）注 7 に同じ

注9）注 7 に同じ

注10)注 7 に同じ

注11) 復興記念館の建設経緯に関しては、『被服廠跡』や『横網町公園』など 東京震災記念事業協会と東京都公園協会で発行した書籍に詳しく記さ れているものの、設計経緯については論じられていない（東京震災記念 事業協会清算事務所編：被服廠跡，東京震災記念事業協会清算事務所， 1932/加藤雍太郎, 中島宏, 木暮亘男：横網町公園一東京都慰霊堂 · 復興記念館，東京都公園協会，2009，ほか)。

注12)これまで復興記念館の設計者については、東京震災記念事業協会（建築 学会：東京都復興記念館新築工事概要，建築雑誌，第 45 巻，第 548 号, 建築学会, pp. 47-48, 1931. 8)、伊東忠太と佐野利器（東京都都市整備 局：東京都選定歷史的建造物と特に景観上重要な歷史的建造物等 歴史 的な資源を生かした景観づくり， p. 3， 2015.3)、伊東忠太と萩原孝一 （日本建築学会：東京都復興記念館の保存に関する要望書，1997）、萩 原孝一（(株）ユーシープランニング：東京都復興記念館の建築につい ての調查報告書, 私家版, p. 12，1997.2）と、意見が分かれている。

注13) 東京震災記念事業協会清算事務所編：被服廠跡，東京震災記念事業協 会清算事務所, 1932

注14）筆者は 2016（平成 28）年 5 月より 2017 (平成 29）年 7 月までに東京都 慰霊協会所蔵資料のうち震災記念堂収蔵庫資料 1941 件のデータベース 化作業を実施した。復興記念館にも収蔵庫があるが、小学生の日誌や震 災時の惨禍を描いた絵画や写真など館内展示に関連する資料が殆どで あったため、今回の作業では除外とした。このうち復興記念館の設計に 関する図面は表 2 の通りである。「協会」所蔵の場合は資料番号を同時 に記した。

Table2 Drawings about Great Kanto Earthquake Memorial Museum 表 2 収集できた復興記念館の図面一覧

\begin{tabular}{|c|c|c|}
\hline Date 時期 & Name 図面名 & Source 所藏元 \\
\hline 1930.9 .2 & $\begin{array}{l}\text { Front view of the memorial museum } \\
\text { 復興記念館正面図 } \\
\text { Front and side view of the memorial museum } \\
\text { 復興記念館正面図・側面図 }\end{array}$ & $\begin{array}{l}\text { Tokyo Nichi- } \\
\text { Nichi } \\
\text { newspaper } \\
\text { 東京日日新聞 } \\
\text { Hochi } \\
\text { newspaper } \\
\text { 報知新聞 }\end{array}$ \\
\hline $\begin{array}{l}1929.9^{-} \\
1930.3\end{array}$ & $\begin{array}{l}\text { Plan of the memorial museum (scale 1/200） } \\
\text { 震災復興記念館設計図（縮尺 } 1 / 200 ）\end{array}$ & $\begin{array}{l}\text { Association } \\
36-62 \\
\text { 「協会」36-62 } \\
\end{array}$ \\
\hline 1930.9 & $\begin{array}{l}\text { Plan of the memorial museum; front, side, rear } \\
\text { view (scale } 1 / 100 \text { ) } \\
\text { 震災復興記念館設計図 正面側面背面図 (縮尺 } \\
1 / 100 \text { ) }\end{array}$ & $\begin{array}{l}\text { Association } \\
36-64 \\
\text { 協会」36-64 }\end{array}$ \\
\hline 1927.6.1 & $\begin{array}{l}\text { Plan of earthquake memorial tower; the } \\
\text { construction of the storage (scale } 1 / 10,1,20 \text { ) } \\
\text { 震災記念塔設計図 記念品保管庫新築工事(縮 } \\
\text { 尺 } 1 / 10 、 1 / 20 \text { ) }\end{array}$ & $\begin{array}{l}\text { Association } \\
37-14 \\
\text { 「協会」37-14 }\end{array}$ \\
\hline 1930.9 & $\begin{array}{l}\text { Plan of the memorial museum; floor, roof } \\
\text { plan (scale } 1 / 100 \text { ) } \\
\text { 震災復興記念館設計図 各平面屋根伏天井伏 } \\
\text { (縮尺 } 1 / 100 \text { ) }\end{array}$ & $\begin{array}{l}\text { Association } \\
40-49 \\
\text { 「協会」40-49 }\end{array}$ \\
\hline 1930.9 & $\begin{array}{l}\text { Plan of the memorial museum; cross, } \\
\text { longitudinal section (scale } 1 / 100)\end{array}$ & $\begin{array}{l}\text { Association } \\
40-50\end{array}$ \\
\hline
\end{tabular}




\begin{tabular}{|c|c|c|}
\hline & $\begin{array}{l}\text { 震㷋復興記念館設計図 横断及び縦断面図(縮 } \\
\text { 尺 } 1 / 100)\end{array}$ & 「協会 \\
\hline 1930.9 & $\begin{array}{l}\text { Plan of the memorial museum; detail view of } \\
\text { the stair hall (scale } 1 / 20 \text { ) } \\
\text { 震災復興記念館設計図 階段室詳細図（縮尺 } \\
1 / 20 ）\end{array}$ & $\begin{array}{l}\text { Association } \\
40-51 \\
\text { 「協会」40-51 }\end{array}$ \\
\hline 1930.9 & $\begin{array}{l}\text { Plan of the memorial museum; side sectional } \\
\text { details (scale } 1 / 20 \text { ) } \\
\text { 震災復興記念館設計図 側面矩計図（縮尺 } \\
1 / 20 ）\end{array}$ & $\begin{array}{l}\text { Association } \\
40-52 \\
\text { 「協会 } 40-52\end{array}$ \\
\hline 1930.9 & $\begin{array}{l}\text { Plan of the memorial museum; detail view of the } \\
\text { entrance (scale } 1 / 20 \text { ) } \\
\text { 震災復興記念館設計図 正面入り口詳細図 (縮 } \\
\text { 尺 } 1 / 20 \text { ) }\end{array}$ & $\begin{array}{l}\text { Association } \\
40-53 \\
\text { 「協会」40-53 }\end{array}$ \\
\hline 1930.9 & $\begin{array}{l}\text { Plan of the memorial museum; sectional } \\
\text { details of reinforced steel (scale } 1 / 20 \text { ) } \\
\text { 震災復興記念館設計図 鉄筋矩計図（縮尺 } \\
1 / 20 \text { ) }\end{array}$ & $\begin{array}{l}\text { Association } \\
40-54 \\
\text { 「協会」40-54 }\end{array}$ \\
\hline 1930.9 & $\begin{array}{l}\text { Plan of the memorial museum; arrangement } \\
\text { plan (scale 1/600) } \\
\text { 震災復興記念館設計図＼cjkstart配置図（縮尺 } 1 / 600 ）\end{array}$ & $\begin{array}{l}\text { Association } \\
40-55 \\
\text { 協会 } 40-55\end{array}$ \\
\hline 1930.9 & $\begin{array}{l}\text { Plan of the memorial museum; full-scale } \\
\text { drawing of the roof made from ironwork } \\
\text { 震災復興記念館 新築工事屋根鉄製様子現寸 } \\
\text { 図 } 1\end{array}$ & $\begin{array}{l}\text { Association } \\
40-56 \\
\text { 「協会」40-56 }\end{array}$ \\
\hline 1930.9 & $\begin{array}{l}\text { Plan of the memorial museum; cross section } \\
\text { of the structure material } \\
\text { 震災復興記念馆設計図 構造材断面図 IX }\end{array}$ & $\begin{array}{l}\text { Association } \\
40-57 \\
\text { 「協会 } 40-57\end{array}$ \\
\hline- & $\begin{array}{l}\text { Arrangement plan of the memorial } \\
\text { museum's exhibit case, part1 } \\
\text { 震災復興記念館 陳列戸棚配置図 その } 1 \\
\end{array}$ & $\begin{array}{l}\text { Association } \\
40-59 \\
\text { 「協会」40-59 }\end{array}$ \\
\hline- & $\begin{array}{l}\text { Arrangement plan of the memorial } \\
\text { museum's exhibit case, part2 } \\
\text { 震災復興記念館 陳列戸棚配置図 その } 2\end{array}$ & \\
\hline- & $\begin{array}{l}\text { Design of the memorial museum's lighting } \\
\text { equipment } \\
\text { 震災復興記念館照明器具図案 }\end{array}$ & $\begin{array}{l}\text { Association } \\
40-61 \\
\text { 脇会 } 40-61\end{array}$ \\
\hline 1930.9 & 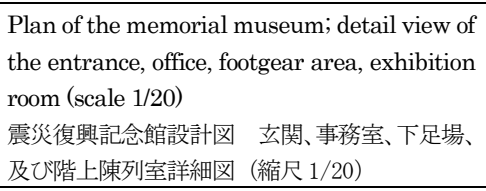 & $\begin{array}{l}\text { Association } \\
40-62 \\
\text { 「協会 } 40-62\end{array}$ \\
\hline 1930.9 & $\begin{array}{l}\text { Plan of the memorial museum; detail view of } \\
\text { toilet and storage (scale } 1 / 20 \text { ) } \\
\text { 震災復興記念館設計図 便所及び倉庫詳細図 } \\
\text { (縮尺 } 1 / 20 \text { ) }\end{array}$ & $\begin{array}{l}\text { Association } \\
40-63 \\
\text { 「協会」40-63 }\end{array}$ \\
\hline- & $\begin{array}{l}\text { Change the sash of the memorial museum, } \\
\text { ver.6 } \\
\text { 震災復興記念館 サッシ変更図 } 6 \\
\end{array}$ & $\begin{array}{l}\text { Association } \\
40-64 \\
\text { 「協会 } 40-64\end{array}$ \\
\hline - & $\begin{array}{l}\text { Change the sash of the memorial museum, } \\
\text { ver.7 } \\
\text { 震災復興記念館 サッシ変更図 } 7\end{array}$ & \\
\hline- & $\begin{array}{l}\text { Exhibition plan of the memorial museum } \\
\text { 復興記念館陳列計画図 }\end{array}$ & $\begin{array}{l}\text { Association } \\
40-71 \\
\text { 「協会」40-71 } \\
\end{array}$ \\
\hline - & $\begin{array}{l}\text { Vicinity and construction plan of memorial } \\
\text { museum } \\
\text { 復興記念館位置案内図・構造図 }\end{array}$ & $\begin{array}{l}\text { Association } \\
40-72 \\
\text { 「協会」40-72 }\end{array}$ \\
\hline 1930.12 .2 & $\begin{array}{l}\text { Detail view of the entrance's design change } \\
\text { 記念館玄関設計変更詳細図 }\end{array}$ & $\begin{array}{l}\text { Tokyo Green } \\
\text { Library } \\
\text { 緑の図書館 }\end{array}$ \\
\hline
\end{tabular}

注15)新聞記事は当時五大新聞として普及率が高かったと考えられる新聞と して、全国紙のうち『朝日新聞』と『読売新聞』を、東京を中心とした 地方紙のうち『東京日日新聞』と『都新聞』、『報知新聞』を対象とし、 『朝日新聞』で 3 件、『読売新聞』で 2 件、『都新聞』で 4 件、『東京日
日新聞』で 3 件、『報知新聞』で 4 件の、全 16 件の関連記事が収集でき た。また、建築系雑誌は『建築雑誌』『建築世界』『建築画報』『建築新 潮』『朝鮮と建築』『住宅』『土建築工事画報』『土建築雑誌』区事の 友』のうち、『建築雑誌』で工事概要と落成を知らせる 2 件と、このほ か『東京市広報』で 2 件、『都市問題』で 2 件の、全 6 件の関連記事が 確認できた。なお、『明治・大正・昭和前期雑誌記事索引集成』、東京文 化財研究所の「文化財関係文献の検索」(http://www. tobunken. go. jp /archives/文化財関係文献の検索/）など、美術関係を含めた雑誌記事 も幅広く検討したが、関連記事は確認できなかった。以上の資料は復興 記念館の収蔵資料や開館式に関する記事が大半を占めており、建築意匠 に関する記述は殆どなかった。

注16)前掲注 13）被服廠跡, p. 84

注17) 震災復興展覧会は、1924 (大正 13) 年 9 月 1 日より 30 日まで、上野自治 会館と池之端において開催された。上野自治会館では震災記念資料とし て震災応急事業の概況を示寸各種の統計・絵画・写真や、当時の惨状を 示す写真や罹災物品を陳列し、池之端では復興参考資料として建築材料 や生活改善の資料、帝国飛行協会出品の防空模型などを陳列した (加藤 龍治：震災復興展覧会開始，官報，p. 3， 1924.9.10)。

注18) 出品者の大半が行方不明で、想定したほどの成果は得られなかった（前 掲注 13）被服廠跡，p. 213)。

注19)以上は前稿に詳しい（注 2 に同じ)。

注20) 都新聞社：寄贈資料を集め震災記念博物館 愈よ九月一日から起工寸 る 被服廠跡の記念堂に，都新聞，朝刊，p12，1927.5.4

注21) 帝都復興展覽会は、1929 (昭和 4) 年 10 月 19 日より 11 月 10 日まで、東 京市政調查会館において開催された。各方面の協力で復興事業が進まれ た震災後の様子を展示することで、大災害への思いを遡る市民の反省資 料としながらも、震災後の物的復興を整えることが開催目的であった。 官公庁や学術研究団体、一般の人々に資料提供を依頼して 85 の出品者 から約 7 万点に及ぶ資料の提供があり、関東大震災と復興、復興帝都の 姿勢に関する資料が陳列された（吉山真棹：帝都復興展の開会と其実績 /帝都復興展覧会総説, 都市問題, 第 10 巻, 第 1 号, 東京市政調查会, pp. 3-24, 1930.1)。

注22）横浜市震災記念館は、横浜市建築課・井上杭一の設計で 1928（昭和 3） 年 8 月 1 日に竣工された、日本最初の震災記念館である。鉄筋コンクリ 一ト構造にセセッション様式の影響がうかがえる洋風意匠であった。

注23) 佐野利器（1880～1956） は、当時東京市建築局長として震災記念堂の設 計競技参考図案の設計に関わり、また、設計競技審査委員として一等案 となった前田健二郎の案を推鹰した。その後、前田案を基にして実施設 計案を作成したが、洋風意匠に対する人々の反対により却下された。以 上、前稿に詳しい（注 2 に同じ）。なお、佐野は 1927（昭和 2）年 5 月 より 1930 (昭和 5) 年 10 月まで「協会」建築顧問を務めた（前掲注 13） 被服廠跡, p. 40)。このため、復興記念館の設計に関与した可能性が考 えられるが、この時点での設計案の詳細は不明である。

注24）報知新聞にも同様な内容が報じられているが、都新聞では延建坪が九千 坪、報知新聞では建坪が千坪と、坪数の記述に相違がある（都新聞社： 明春の復興祭泛に震災記念館 被服廠跡か安田邸跡資金世万圓は寄 付で, 都新聞, 朝刊, p. 12, 1929.11.5/報知社：焼残りを蒐め震災記 念館 新たに市で建設に着手 工費三十萬圓は一般寄附, 報知新聞, 夕刊, p. 2, 1929.11.5)。

注25)前掲注 13）被服廠跡，p. 203

注26）天皇の巡幸は、九段坂上、府立工芸学校、上野公園、隅田公園、震災記 念堂、市立千代田小学校、市立築地病院の 7 力所で行われた（東京朝日 新聞社：光栄に輝く御道筋 御出門より還幸まで，朝日新聞，夕刊， p. 1, 1930.3.6)。

注27) 図面の情報を読み取りやすくする工夫として、破線で「記念館」の位置 を表記した (東京震災記念事業協会: 震災記念堂地域図, 東京都慰霊協 会所蔵 36-04)。

注28) 東京震災記念事業協会：震災復興記念館設計図，東京都慰霊協会所蔵 $36-62$

注29)この時期における同種の建築としては横浜震災記念館の他に丹後震災 記念館が存在した。京都府土木課営繕係・一井丸平により設計された丹 後震災記念館（1929（昭和 4）年 12月竣工）は、1927（昭和 2）年 3 月 7 日の北丹後地震の震災記念館として計画された。建物正面のポーチ、 アーチ状の開口部と軒先のディテールなど、横浜市震災記念館と意匠的 類似性がうかがえる洋風意匠の鉄筋コンクリート構造二階建てで建て られた。第一案も、同種の建築に用いられた洋風意匠の影響を受けた可 
能性が考えられる。

注30)注 28 に同じ

注31) 注 28 に同じ

注32) 井下清（1884～1973）は香川県出身で、1905（明治 38）年に東京高等農 学校 (現東京農業大学) を卒業後、東京市公園課課長、東京市公園課部 長、東京都公園緑地課長など、東京都の公園行政及び全国の造園関連事 業の発展に尽くした。また、震災記念堂の最初計画案を設計するなど、 横網町公園の建設計画に深く関わった人物である。

注33) 都新聞によると、「東京市では復興記念に被服廠跡の震災記念堂と並べ て震災陳列館をつくり、これに大震災當時の焼失破壊の記念物を全部納 めて當時の情景を永久に残し、これを記念しやうと云ふ計畫が現に井下 公園課長を中心に研究されている」と、復興記念館の設計に関する井下 の関与が報じられている (都新聞社：東京市では震災陳列館 被服廠跡 一, 都新聞, 朝刊, p. 12, 1930.3.25)。しかし、計画案の具体的な記述 や図面などの詳細は掲載されておらず、この他、井下の設計関与を裏付 ける資料も確認できない。

注34) 報知新聞にも第二案の正面図と側面図が掲載されており、このうち正面 図は図 5 と同一形状であった（報知新聞社：『震災博物館』として生れ る復興記念館 横死者の所持金等を基として明春までには完成, 報知 新聞, 夕刊, p. 2, 1930.9.3)。しかし、このほか第二案の計画が確認で きる資料はない。

注35）前掲注 13）被服廠跡, p. 204

注36) 萩原孝一（1895～1977）は岡山県出身で、1921（大正 10）年に東京帝国 大学を卒業し、朝鮮総督府技手として嘱託された。1926（大正 15）年 4 月から 1931（昭和 6) 年 8 月 31 日までは東京に戻り「協会」の建築技 師として横網町公園内建造物の建設計画に関わるが、工事が終了される と再び朝鮮に渡る。その後、京城府営䋨課建築技師として数多くの建築 に手がけながら、1938（昭和 13）年より 1942（昭和 17）年まで朝鮮建 築会会長を務めるなど、戦前期における朝鮮の建築に多大な影響を与え た。自筆経歴書によると、朝鮮では 24 棟の公共建築に手がけており、 このうち外観形状が確認できる 15 棟は大学の卒業設計及び論文で提案 したシンプルでモダンなスタイルが多く見られた。定年退職した戦後は 日本一戻り、萩原建設株式会社を開いて建築活動を続けた。以上、大学 の卒業設計を含めて萩原が朝鮮で手がけた建築活動の概要は前稿でま とめており、今後別稿で詳細に論じる予定である（姜明采, 内田青蔵: 朝鮮建築会会長・萩原孝一について一朝鮮での建築活動を中心として一, 日本建築学会大会学術講演梗概集 (東北), 日本建築学会, pp. 987-988, 2018. 9)。

注37）青焼き図面の押印を基に『被服廠跡』に記された職員名簿と震災記念堂 収蔵庫にある職員給料請求書を照らし合わせて担当者を特定した（前掲 注 13）被服廠跡，pp. 24-26／東京震災記念事業協会：工事竣工(検査) 調書, 東京都慰霊協会所蔵 36-29／東京震災記念事業協会：請求書, 東 京都慰霊協会所蔵 36-46)。

注38) 東京震災記念事業協会：震災復興記念館設計図各平面屋根伏天井伏, 東京都慰霊協会所蔵 40-49, 1930.9

注39)アプスのような台形状平面の背面空間は、震災記念堂で見るバシリカ式 平面形状に影響を受けた可能性が考えられるが、最終的には全体的に長 方形の形状として統一された。変更の理由は不明であるが、設計者であ ると考えられる萩原の作風が影響した可能性が推察できる。

注40）前掲注 13）被服廠跡, p. 205

注41) 東京震災記念事業協会: 震災復興記念館設計図正面側面背面図, 東京 都慰霊協会所蔵 36-64, 1930.9

注42) 東京震災記念事業協会：震災復興記念館設計図正面入り口詳細図，東 京都慰霊協会所蔵 40-53, 1930.9

注43) 塔が無くなった理由は不明であるが、震災記念堂の設計競技一等案を基 にした実施案は塔を持つ洋風意匠で、多くの人々に意匠的批判を受けた 経緯がある。第二案も塔状という意匠的類似性から人々の批判を意識し た可能性が考えられる。以上、震災記念堂に対する意匠的批判について は前稿に詳しい(注 2 に同じ)。

注44）「古代インドで理想の国王とされる転輪聖王の感得する七宝の一つ。転 輪聖王遊行の時、必ず先行して四方を制するという。金・銀・銅・鉄の 四種がある。もとインドの武器。」(新村出編：広辞苑 第六版, 岩波書 店，p. 2972，2011)

注45) 藤森照信は、復興記念館の「軒と屋根を除いては日本風や東洋風が見ら れず、伊東らしからぬ（原文まま）デザインともいえるが、しかし、正 面の付け柱の上部には伊東ならではの怪獣がいる。建物の高い所に怪獣
がちょこりと腰を下ろし下を見下ろすというポーズは、ゴシック教会の 軒先の空想獣から来ている」とし怪獣が伊東らしい意匠であると評価し た。しかし、伊東がどこまで手掛けたのかは疑問であると述べている(伊 東忠太, 藤森照信, 増田彰久: 伊東忠太動物園, 筑摩書房, pp. 86-90, 1995)。

注46) 注 42 に同じ

注47) 東京震災記念事業協会：震災復興記念館設計図側面矩計図，東京都慰 霊協会所蔵 40-52, 1930.9

注48) 藤岡洋保はアール・デコ様式の特徵として、「金属を多用し、ジグザグ 模様や放射線など、幾何学的なモチーフを多用する」ことを挙げた（藤 岡洋保：近代建築史（建築学入門シリーズ），森北出版，p. 49，2011）。 また、吉岡鋼市は、神奈川県庁舎（1928（昭和 3）年）や名古屋市役所 本庁舎（1933（昭和 8) 年)、東京国立博物館（1937（昭和 12）年）など を挙げ、昭和初期の公共建築にはアール・デコ様式が多く用いられてお り、いわゆる「日本趣味」の建築はアール・デコ様式として捉えられる と論じた（吉田鋼市：図説アール・デコ建築グローバル・モダンの力 と誇り, 河出書房新社, pp. 112-114, 2010)。

注49）前掲注 13）被服廠跡，p. 210

注50）『東京都復興記念館の建築についての調査報告書』によると、以下の記 述から萩原を設計者として捉えている。「1. 図面にはサインが一つ。「K1」 と読める。(萩原) 孝一と考えられる。2. 原案（第三案と考えられる） の玄関に比較して、笠木、上部のシンボル、照明など意匠上の大幅な変 更が行われている。3. 他にサイン、認印がない事から、この図面を書い た設計者が独断で設計変更を決めた可能性がある。4.この原図がトレ ーシングペーパーの上に、柔らかい鉛筆でスケッチ風に書かれているこ とから、建物設計者のものと考えられる」（前掲注 12）東京都復興記念 館の建築についての調查報告書，p. 12)。また、萩原のご子息への聞き 取り調査より、図面上の「K1」は父親のサインであるという証言も得た。 注51）前掲注 12）東京都復興記念館の建築についての調査報告書，p. 16 注52) 東京震災記念事業協会：記念館玄関設計変更詳細図, 緑の図書館所蔵 注53)注 35 に同じ

注54) 前掲注 12) 東京市復興記念館新築工事概要, p. 47

注55）鈴木博之・山口廣は、具体的な事例として、明治神宮宝物殿（1921（大 正 $10 ）$ 年)、東京歌舞伎座（1924（大正 13）年)、神奈川県庁舎 (1928 (昭和 3) 年)、震災記念堂（1930（昭和 5）年）などを挙げている（鈴 木博之・山口廣『新建築学大系 5』彰国社，p. 440，1993）。以上、当時 の建築界では「東洋趣味」と「日本趣味」の建築意匠を混乱して認識し ていたことが考えられる。

注56) 藤岡によると、昭和初期に合理主義の建築家たちは東洋風の社寺建築に 起因した意匠的要素を日本的なものとして捉えることに対し、日本の建 築的伝統についての認識が曖昧となり、非合理的であると批判した。さ らに、中国建築の影響を排除した日本固有の神社や住宅、茶室に起因す るモチーフとした平面・構造の簡素・明快さ、素材の美の尊重、無装飾、 左右非相称、自然（建物周囲の環境）との調和、規格統一 (畳の規格) の 6 項目を新たな日本的なものとして主張した（藤岡洋保：昭和初期の 日本の建築界における「日本的なもの」一合理主義の建築家による新し い伝統理解一, 日本建築学会計画系論文報告集, 第 412 号, 日本建築 学会, pp. 173-180, 1990.6)。

注57) 各案における「日本趣味」の意匠的要素を屋根、細部、塔に大きく分け、 各部分に影響を与えた意匠として社寺風、アール・デコ風と記した。 


\title{
THE CONSTRUCTION PROCESS OF GREAT KANTO EARTHQUAKE MEMORIAL MUSEUM
}

The Nihon-Shumi (Japan-Taste) required to the building in Yokoamicho Park

\author{
Myungchae KANG ${ }^{* 1}$, Seizo UCHIDA*2 and Fumiyo SUZAKI*3 \\ ${ }^{* 1}$ Grad. Student, Dept. of Architecture, Faculty of Engineering, Kanagawa University, M.Eng. \\ ${ }^{* 2}$ Prof., Dept. of Architecture, Faculty of Engineering, Kanagawa University, Dr.Eng. \\ *3 Assist. Prof., Dept. of Architecture, Faculty of Engineering, Kanagawa University, Dr.Eng.
}

This paper states concerning the characteristics of the Nihon-Shumi(Japan-Taste) architecture in Yokoamicho Park. These buildings are additional facilities of the Memorial Hall for Great Kanto Earthquake that discussed in ahead of this research. The paper clarified the construction process of Great Kanto Earthquake Memorial Museum which built in 1931. In this study, the project report of the Great Kanto Earthquake Association and materials in the storage of Memorial Hall for Great Kanto Earthquake are used as the main requirements to analyze the construction of the Memorial Museum. Also, the news articles are used as the requirements, 22pieces of articles were collected by the newspaper; Asahi, Yomiuri, Tokyo Nichi-Nichi, Miyako, Hochi which published in Tokyo and throughout Japan, From 1923 to 1931.

As the result, the design of Memorial Museum has been changed 3 times. At first, the Museum was constructed from 9th November 1929 to 24th March 1930. The elevation was composed of symmetry influenced by classicism style. The Japanese shrines and temple style was well expressed in a roof and a piece of wood supporting deeply recessed eaves, esp. in Japanese shrines and temple construction, curve shape in decoration, garden lantern.

However, the newspaper reported that the Museum's design changed on 3rd September in 1930 that was after the construction of Memorial Hall. The change was embodied the Japanese shrines and temple style such as the roof style, final of the pagoda.

Finally, the design was changed again before the Memorial Museum's construction on 26th September 1930. The blueprint drawings that drew up on September 1930 shows that the floor plan based on the first plan, and the elevation plan based on the second plan. It can be inferred that the designer was Koichi Hagiwara, the construction engineer of the Great Kanto Earthquake Association. Also, the floor and elevation plan transformed to rectangle-shape, and the style was changed uniquely such as circle decoration in the door and the monster sculpture in elevation. In the $3^{\text {rd }}$ design, the Japanese shrines and temple style changed to the modern and simple elements in the details of roof and door, etc. Furthermore, it had influenced by Art Deco Style and it could be presumed the possibility that the simple and modern style of $3^{\text {rd }}$ design was related to the main designer, Hagiwara. He asserted that style through his other architectural activities.

So, it makes clear that the design of Memorial Museum was originally planned to Nihon-Shumi(Japan-Taste) architecture. Also, it was mainly based on Japanese shrines and temple style as an extension of the Memorial Hall's design that was based on traditional Japanese style. But, Memorial Museum had adapted to the trend and suggested the new expression of Japanese shrines and temple style with details influenced by Art Deco style. Also, it can be assumed that Memorial Museum's design was reflected the times that was changing the concept to express NihonShumi(Japan-Taste). The reason why the Museum planned Nihon-Shumi(Japan-Taste) architecture can guess the relations with the Memorial Hall which is the main building in Yokoamicho Park. 